\title{
Digital Humanities and Social Change: an Interview with Alex Gil
}

Alex Gil

Interviewers:

Marcela Santos Brigida ${ }^{\dagger}$

Gabriela Ribeiro Nunes*

While it is not yet possible to gauge the long-term impacts of the shifts brought on by the experiences of 2020, it seems safe to assume this year will be remembered by the many critical events that precipitated change in the ways humans relate to each other and to our environment. The most far-reaching of those is, of course, the COVID-19 pandemic. However, the Black Lives Matter marches, popular demonstrations against totalitarian governments throughout the world, as well as deeply concerning tippingpoints regarding climate change are all part of a collective conversation we feel the urge to engage with. Nearly six months into our own experience with the pandemic in Brazil, after the loss of more than one hundred thousand lives to COVID-19, we at Palimpsesto aim at publishing pieces that not only acknowledge the circumstances under which they were written, but that also engage and produce critical thinking about them. It was

\footnotetext{
*Alex Gil (Ph.D., English Language and Literature, University of Virginia, 2012; Ancien Pensionnaire, Ecole Normale Supérieure, 2007; M.A., English Language and Literature, University of Virginia, 2005; B.A., English, Florida International University, 1999) is the Digital Scholarship Librarian at Columbia University Libraries. He collaborates with faculty, students and library professionals leveraging computational and network technologies in humanities research, pedagogy and knowledge production. He is among the founders of several ongoing, warmly received initiatives where he currently plays leadership roles: Co-director of the Studio@Butler at Columbia University, a tech-light library innovation space focused on digital scholarship and pedagogy; co-founder and moderator of Columbia's Group for Experimental Methods in the Humanities, a vibrant trans-disciplinary research cluster focused on experimental humanities; senior editor of sx archipelagos, a journal of Caribbean Digital Studies, and cowrangler of The Caribbean Digital conference series. He is also founder and former chair of Global Outlook::Digital Humanities. Read more at:

http://www.elotroalex.com/
}

\footnotetext{
$\dagger \mathrm{PhD}$ Student in Literary Studies at Universidade do Estado do Rio de Janeiro (UERJ). CNPq Scholar. https://orcid.org/0000-0002-0951-1603 | marcela.brigida@uerj.br $\$$ PhD student in Literatury Theory/Comparative Literature at Universidade do Estado do Rio de Janeiro
(UERJ). E-mail: j15c17g11@ @ hotmail.com | ORCID: https://orcid.org/0000-0002-6593-0351.
} 
within this spirit, and not only considering this issue's theme - "Literature Teaching in Digital Contexts: Dialogues and Connections" - that we approached Dr. Alex Gil and asked him for an interview.

Alex Gil is a well-known scholar in the field of Digital Humanities not only for his work as a Digital Scholarship Librarian at Columbia University Libraries or as a developer of ingenious projects, but also for the fact that he often directs his abilities to produce tools that help promote social change. Dr. Gil has developed and collaborated in several of such efforts, as we discuss throughout our interview. Bearing Witness, one of his most recent initiatives, has been jointly announced by him and Prof. Samuel Roberts (Columbia University) and appears as "an effort to document and interpret the events associated with the novel coronavirus epidemic in the United States as it pertains to racialized minorities". We strongly recommend that you read more about the Mobilized Humanities interventions in the links available at the end of this piece.

It has been truly delightful to discuss Alex Gil's projects and to consider how each of us - as students, researchers, and teachers - can work in the humanities to acquire new skills to produce change. The discussion around the place of the university amid this crisis, as an institution, is also one that deeply interests us. Finally, Gil is a prominent Aimé Césaire scholar. Discussing the work produced by this writer and thinker - at a moment when Discourse on Colonialism has been released in a new Brazilian edition - also seems to be a crucial exercise to try to make sense of our questions - in a local and in a global scale - with a critical eye. We are thankful to Dr. Alex Gil for taking the time to talk to us amid the 2020 chaos as well as for the thoughtprovoking insights he has brought to us, which we now proudly share with Palimpsesto's readers.

\section{PALIMPSESTO}

1) Could you tell us a little about your work as a Digital Scholarship Librarian at Columbia University Libraries? What does your collaboration with faculty and students entail? 


\section{ALEX GIL}

First of all, thank you for inviting me to share my work with your readers. I'm delighted. My work involves a few activities: more often than not, I'm collaborating with faculty and students in the humanistic disciplines on a digital project. I tend to think that advanced work with computers in the humanities falls in one of two camps: the use of algorithms to study patterns in digitized cultural artifacts, or the architecture of technical and social structures of knowledge production. I can help with many genres of projects that fall within these two broad spheres: maps or visualizations, text analysis, digital archives of cultural artifacts, digital editions of historical documents, and much more. In some cases, I'm just available for a quick consultation, in others I teach courses on these subjects, or use a project as an excuse to teach these subjects, and in some cases focus on special projects as a team member.

\section{PALIMPSESTO}

2) You have an impressive range of projects that are currently ongoing. We were particularly intrigued by $E d$., a digital platform for editing literary texts which "can produce beautifully rendered scholarly or reading editions of texts meant to last". How can digital humanities enthusiasts begin to work with a platform like that? Do you think an education in programming is a key skill for a Humanities professional to work with digital tools and methods or could a transdisciplinary team fulfill that necessity?

\section{ALEX GIL}

Ed is meant for intermediate students. You need to learn certain fundamentals of computation before you can use something like Ed independently of someone who has these skills to help you. To be clear, the skills I am talking about can be learned without taking courses in computer science or engineering. These fundamentals are only the tip of the iceberg of what one learns in these schools. Surprisingly, though, you can go very far with just the basics. I should know, since that is all I know. That said, I do not believe learning these fundamentals is for everybody. These are meant for those who really want to control the production of their own knowledge; or, for those who really 
want to understand what the algorithms are telling them or not telling them about their objects of study.

To answer your question even more specifically, I do think some interdisciplinary teams are a good thing. Sometimes that "interdisciplinarity" comes from within the humanities itself. All you need is one or two programmers in one team of humanists to do most of these things. I myself have a doctorate in literature. If you have me in your team, you may not need an engineer or a computer scientist. In fact, chances are inviting someone from these fields would be overkill. When we consider the professional world outside of professors and librarians, this "interdisciplinarity" takes on a different meaning. Now we're talking about different companies and institutions "collaborating" in the market. Think of the way a book is made. Several industries are "collaborators" in the production, distribution and stewardship of each one of these objects, but this is only possible because that object becomes a commodity. Digital projects are not that far from these market ecologies, and many teams of humanists today rely on companies that provide engineers and designers. Whether this is or not the best way to go about creating our artifacts or doing our research is a different question.

\section{PALIMPSESTO}

3) We have seen, in the past few years, a rise of totalitarian tendencies and even neofascist discourse in several countries. While social media has often played an important part in reporting abuse and police brutality to a wider, international audience, it seems it has also been instrumentalized by the alt-right to organize, promote mass misinformation and naturalize problematic discourses. In Brazil, politicians and highrank officials who are part of the current administration have recently been accused of neo-Nazi dog whistling in Twitter posts and YouTube live transmissions due to their taking part in something called "Desafio do Leite" (The Milk Challenge) (Cf. SACONI, 2020). Do you think digital humanities tools and technology could help us expose and disarticulate such practices? How?

\section{ALEX GIL}

I am afraid that the most important 'technological' work may need to come from the companies that provide these platforms that facilitate the dissemination of these campaigns in the first place. That said, you should continue to produce cultural artifacts 
that fight shrewdly against these people and their message. Fight them with any tool you have available to you, even the same platforms. And remember, in the case of getting rid of Bolsonaro and fascism in Brazil, or Trumpism in the USA, we have only two choices: revolution or voting. Perhaps you can use the techniques and practices of digital humanities to tell stories, or to share knowledge, that will motivate people to do one of those two things. Be clear about which one you're picking and dedicate yourself to it.

Getting rid of the fascists is not the end of the story, though. We've been here before in human history. Chances are, whatever your project is, it will be telling those stories or sharing that knowledge, addressing one or two of the symptoms of these governments, but also the legacy of the past 500 years. This is all good, because you may need to continue after the fascists are gone. Take for example our project Torn Apart/Separados, against the Immigration Control and Enforcement (ICE) police force. We imagine we will have to continue working against them long after Trump is gone.

\section{PALIMPSESTO}

4) You are one of the founders of the Group for Experimental Methods in the Humanities at Columbia, a group that does not maintain an official membership list, sharing instead a list of contributors and naming the group's moderators, whom those who are interested in participating can contact to learn how they can get involved. Have you seen an increase of requests from people interested in collaborating with you since the pandemic began? Do you believe social distancing will propel more people in the Humanities towards experimenting with digital methods in their teaching practices in a long-term basis, for instance?

\section{ALEX GIL}

We haven't seen an increase in membership at xpmethod. All the contrary. We've seen a reduction. Our group usually met on Fridays at the Butler Library of Columbia, in a room I manage called the Butler Studio. Since we're not allowed to meet with each other anymore, we have seen a decrease in active participation. This is 
perfectly understandable. A few of us are already discussing ways to try to compensate for that absence in the Fall semester using techniques like broadcasting and messaging.

Yes, I personally have been asked to collaborate on many more projects since the pandemic started. Sadly, I can't accept all collaborations because time is finite. I think this is great, and I just wish there were many more professionals like me to go around so we could all help each other out these days.

I honestly don't know if people will incorporate more digital methods permanently in the long term. Maybe there will be a slight increase because of by the end of the pandemic they will have some practice. Hard to predict.

\section{PALIMPSESTO}

5) You and Prof. Samuel Roberts have recently announced a new project titled Bearing Witness, "an effort to document and interpret the events associated with the novel coronavirus epidemic in the United States as it pertains to racialized minorities." Torn Apart/Separados, is another of your projects that employ digital scholarship to raise social awareness and help promote change. Could you tell us a bit more about the Mobilized Humanities interventions?

\section{ALEX GIL}

The idea is simple: Use what you know to make the world a better place, to fight, to rebel against evil. We know so much in the humanities: we know history, how to read closely, how to teach, how to make arguments, how to tell stories, how to organize knowledge, how to do research, how to critique, to question what we're told, and yes, how to code, how to make interactive websites, documentary films, podcasts, books, and so much more. We should use all of that to go down fighting into that good night, to bear witness to evil, to show up, and even to save lives. If all we're doing is contributing to some encyclopedic knowledge of the world, we've failed at the gift of life.

\section{PALIMPSESTO}


6) You are, of course, a world-renowned Aimé Césaire scholar, responsible for the discovery of the earliest known manuscript version of Et les chiens se taisaient. How did you become a reader of Césaire and why did you decide to write your dissertation about him? What can we learn from Césaire in a moment of crisis such as the one we are living through in 2020 ?

\section{ALEX GIL}

Aimé Césaire is immensely relevant, perhaps more than when I started studying his poetry and theater in grad school. I started working on him around the same time as I started flirting with digital humanities. I was interested in doing a database of Caribbean authors in those days. I was partnered with a professor in the French department at the University of Virginia who was a scholar of Césaire, so I agreed to start there, by doing a digital edition of his masterpiece, The Notebook of a Return to the Native Land. Next thing you know, I was writing a dissertation about the poet.

Césaire is such a rich figure, and gave us so much, that it is difficult for me to cover all the ways in which his work is relevant today. I recommend you read "Discours sur le colonialisme" ("Discourse on Colonialism") to start. In this powerful essay he argues that the techniques of colonialism will come back to destroy European societies. Today we're seeing government thugs dressed in military gear put citizens in unmarked vehicles in the United States, supposedly the world's "greatest democracy." These same thugs dressed in military gear were putting denizens in unmarked vehicles just yesterday in the same country. "Illegals" they called them. This is an example of that boomerang effect that Césaire describes in this essay. His poetry and theater, of course, is where I find the much richer treasure: from recipes against assimilation to manuals for governance of post-colonial societies. Don't take my word for it, though, go out and read his books.

\section{PALIMPSESTO}

7) The pandemic has forced many schools and universities to find new models for teaching and learning. In many countries, Brazil included, it has also exacerbated patterns of inequality that are present in our educational systems. While to some students and parents the issue was how to make lessons work well through 
videoconferencing platforms in a home environment, others have no adequate equipment or even a stable internet connection. Many students live in small homes, which they share with several relatives and do not have a room of their own where they can isolate during classes. What do you make of the current turn towards online teaching and what can we do - as teachers, as researchers, and as students - to make sure the crisis caused by the pandemic does not implicate in further exclusion for people who already face the effects of social inequality in their everyday lives?

\section{ALEX GIL}

I don't know if you noticed when you were doing your research that I am interested in this idea of "minimal computing": the reduction of many forms of computation to meet the needs of humanities work at the most basic level, while avoiding many costs we can't really afford. "Ed" is an example of a project designed with this minimal computing in mind $^{2}$. Such reductions in computation tied to the question of need seem to always force us to be aware of our precise limitations, but also of the potential around us - the deeper truth of our material, lived environment.

I've spent the past decade traveling around the continents, talking to colleagues around the world, observing how scholars, librarians and other cultural workers conduct their business in very different environments: from places without constant electricity to places with heavy government censorship. Throughout these experiences, I've always carried with me the ideas of the Cuban architect and theorist, Ernesto Oroza, who speaks of "Architectures of Necessity" and "Moral Modulors." For him, one of the biggest super-powers of those in need is the ability to see the real material components of the objects around us: what has this metal, what would this be useful for if I broke it in two, etc. Both communism and capitalism, he points out, depend too much on the idea of a finished product, of a commodity. This is perhaps the main reason why countries such as mine, the Dominican Republic, and yours, Brazil, rely so much on imported technological solutions, on "digital humanities tools and software" so to speak. Instead, I invite you to look around and see what you have available to you already. In this machine alone which you are using to read my words, you have a relatively powerful computer, capable of doing computations, of automating tasks outside of graphic interfaces. Do you know how to use it to do that? 


\section{PALIMPSESTO}

8) In Brazil, public universities have endured systematic attacks over the past few years. Our former Education Secretary (who left his post in June 2020) has often attacked the Humanities throughout his tenure in office, having declared earlier this year that "regarding all universities, it should be noted that money does not grow on trees, it comes from taxes. When we buy bread, gas for our motorcycles, when we pay cellphone bills, there is a tax. And this tax is used to pay teachers' salaries, technicians' salaries, students' scholarships, the food they eat, and all that. I, as a Brazilian, want to have more doctors, more nurses, more engineers, more dentists. I don't want more sociologists, anthropologists, I don't want more philosophers with my money". ${ }^{\S}$ Last year, he gained the president's support in a bid to reduce investments in Philosophy courses to prioritize areas that, in his view, could "generate an actual return", such as "Nursing, Veterinary, Engineering, and Medical School". The Humanities undergraduate and graduate courses have also been excluded from the four-year investments plan of one of the country's main scientific funding agencies, CNPq. In a context such as this, do you think digital humanities tools and practices could help us make the work that is developed within the university more widely visible and available to society in general? How could the Humanities work to create and employ technological tools to deconstruct prejudices and counterargument discourse such as the one cited above?

\section{ALEX GIL}

You won't win with these people. Stop trying to convince them. You need to get rid of them, and those three steps to the left of them, until you cross past the center to the real left who think human Life is more than health and money. These people are dangerous idiots, honestly. We have them too further North. Keep in mind that you will probably lose. We all will. We need to start imagining a world in which the Humanities (history, the arts, theory, critique, etc) all exist post-Universities. In a real sense in many countries the Humanities already do live in this world. This other world is trying to tell you something. If you want to really understand the power of these tools, imagine them serving you in this other world.

To help you see this other world, I invite you dwell a bit on the domain of pirate libraries like SciHub and LibGen, and other forms of pirate care ${ }^{3}$ blooming all around us. We didn't ask to live in a world in which caring is a crime, but we must really get

\footnotetext{
$\S \quad$ https://noticias.uol.com.br/colunas/constanca-rezende/2020/06/14/weintraub-nao-quero-sociologoantropologo-e-filosofo-com-meu-dinheiro.htm
} 
good at it until we can get rid of this wild pack of demonic donkeys we've been cursed with in this period of human history.

Thank you for these very smart questions, and again, for giving me an opportunity to share some of my thinking with your readers. Your teachers are really lucky to have you!

\section{References}

GIL, Alex. @elotroalex. Available at: https://www.elotroalex.com/. Accessed on: 25 Aug. 2020.

GIL, Alex. Design for Diversity: The Case of Ed / Alex Gil. Available at: https://des4div.library.northeastern.edu/design-for-diversity-the-case-of-ed-alex-gil. Accessed on: 25 Aug. 2020.

GO::DH. Minimal Computing. Available at: http://go-dh.github.io/mincomp/. Accessed on: 25 Aug. 2020.

MOBILIZED HUMANITIES. Torn Apart/Separados. Available at: http://xpmethod.columbia.edu/torn-apart/volume/2/index. Accessed on: 25 Aug. 2020.

PIRATE CARE. syllabus 乡 Pirate Care. Available at: https://syllabus.pirate.care/. Accessed on 25 Aug. 2020.

SACONI, João Paulo. Entenda: por que o copo de leite na live de Bolsonaro provocou controvérsia. $O$ Globo. 01 Jul. 2020. Available at:

https://blogs.oglobo.globo.com/sonar-a-escuta-das-redes/post/entenda-por-que-o-copode-leite-na-live-de-bolsonaro-provocou-controversia.html Accessed on: 25 Aug. 2020.

TORRENT, Susanna Allés; CATAPANO, Terry; GIL, Alex; GILLIUM, Johann. Ed. Available at: http://elotroalex.github.io/ed/. Accessed on: 25 Aug. 2020. 


\title{
Humanidades digitais e transformação social: uma entrevista com Alex Gil
}

\author{
Alex Gil ${ }^{* *}$ \\ Entrevistadoras: \\ Marcela Santos Brigida ${ }^{\dagger \dagger}$ \\ Gabriela Ribeiro Nunes
}

Embora ainda não seja possível avaliar os impactos de longo prazo das mudanças provocadas pelas experiências de 2020, parece seguro presumir que este ano será lembrado pelos diversos eventos críticos que precipitaram mudanças nas formas como os seres humanos se relacionam entre si e com o ambiente. $\mathrm{O}$ deslocamento de maior alcance é, obviamente, a pandemia do COVID-19. No entanto, as marchas do movimento Black Lives Matter, manifestações populares contra governos totalitários em todo o mundo, bem como o registro de eventos irreversíveis profundamente preocupantes em relação às mudanças climáticas, fazem parte de uma conversa coletiva com a qual sentimos a necessidade de nos envolver. Com quase seis meses de experiência com a pandemia no Brasil, após a perda de mais de cem mil vidas para o COVID-19, nós da Palimpsesto pretendemos publicar textos que não apenas reconheçam as circunstâncias em que foram escritos, mas que também se engajem e

\footnotetext{
** Alex Gil (Doutor em Língua e Literatura Inglesa pela University of Virginia, 2012; Ancien Pensionnaire pela Ecole Normale Supérieure, 2007; Mestre em Língua e Literatura Inglesa pela University of Virginia, 2005; Graduado em Língua Inglesa pela Florida International University, 1999) atua como bibliotecário de conhecimentos digitais [Digital Scholarship Librarian] nas Bibliotecas da Universidade Columbia. Ele colabora com professores, alunos e bibliotecários, alavancando tecnologias computacionais e de rede na pesquisa, pedagogia e produção de conhecimento nas humanidades. Ele está entre os fundadores de várias iniciativas em andamento muito bem recebidas, nas quais atualmente desempenha funções de liderança: Co-diretor do Studio@Butler na Universidade Columbia, um espaço tech-light de inovação para bibliotecas com foco em conhecimentos digitais e pedagogia; cofundador e moderador do Group for Experimental Methods in the Humanities [Grupo de Métodos Experimentais nas Humanidades] na Columbia, um vibrante grupo de pesquisa transdisciplinar com foco em humanidades experimentais; editor sênior do sx archipelagos, um periódico de Caribbean Digital Studies e argumentador na série de conferências The Caribbean Digital. Ele também é fundador e ex-presidente da Global Outlook::Digital Humanities. Leia mais em: http://www.elotroalex.com/

† Doutoranda em Estudos Literários na Universidade do Estado do Rio de Janeiro (UERJ). Bolsista CNPq. https://orcid.org/0000-0002-0951-1603 | marcela.brigida@ uerj.br

\# Doutoranda em Teoria da Literatura/Literatura Comparada pela Universidade do Estado do Rio de Janeiro (UERJ). E-mail: j15c17g11@ hotmail.com | ORCID: https://orcid.org/0000-0002-6593-0351.
} 
produzam pensamento crítico sobre elas. Foi com este espírito, e não apenas considerando o tema desta edição - "Ensino de literatura em contextos digitais: diálogos e conexões" - que procuramos o Dr. Alex Gil e o convidamos para uma entrevista.

Alex Gil é um pesquisador amplamente reconhecido na área das Humanidades Digitais não apenas por seu trabalho como Bibliotecário de Conhecimentos Digitais [Digital Scholarship Librarian] nas Bibliotecas da Universidade Columbia ou como desenvolvedor de projetos engenhosos, mas também pelo fato de que ele frequentemente direciona suas habilidades para produzir ferramentas que ajudam a promover mudanças sociais. O Dr. Gil desenvolveu e colaborou em vários desses esforços, conforme discutimos ao longo de nossa entrevista. Bearing Witness, uma de suas iniciativas mais recentes, foi anunciada em conjunto por ele e pelo Prof. Samuel Roberts (Universidade Columbia) e surge como "um esforço para documentar e interpretar os eventos associados à nova epidemia do coronavírus nos Estados Unidos no que diz respeito a ela às minorias racializadas". Recomendamos fortemente que todos leiam mais sobre as intervenções Mobilized Humanities nos links disponíveis no final desta entrevista.

Foi, de fato, uma experiência extraordinária discutir os projetos de Alex Gil e considerar como cada um de nós - enquanto estudantes, pesquisadores e professores pode trabalhar no campo das humanidades para adquirir novas habilidades e promover mudanças. A discussão em torno do lugar da universidade em meio a esta crise, como instituição, também nos interessa profundamente. Finalmente, Gil é um proeminente pesquisador de Aimé Césaire. Discutir a obra deste escritor e pensador - em um momento em que Discurso sobre o Colonialismo foi lançado em nova edição brasileira - também parece ser um exercício crucial para tentar compreender as nossas questões em uma escala local e global - com um olhar crítico. Somos gratas ao Dr. Alex Gil por conversar conosco em meio ao caos de 2020, bem como pelos insights instigantes que ele trouxe para nós, os quais agora orgulhosamente compartilhamos com os leitores da Palimpsesto.

\section{PALIMPSESTO}


1) Você poderia nos contar um pouco sobre seu trabalho como Digital Scholarship Librarian nas Bibliotecas da Universidade Columbia? Como funciona sua colaboração com professores e alunos?

\section{ALEX GIL}

Em primeiro lugar, obrigado por me convidar a compartilhar meu trabalho com seus leitores. É um prazer. Meu trabalho envolve algumas atividades: na maioria das vezes, colaboro com professores e alunos nas disciplinas humanísticas em um projeto digital. Tendo a pensar que o trabalho avançado com computadores nas humanidades se enquadra em um desses dois campos: o uso de algoritmos para estudar padrões em artefatos culturais digitalizados ou a arquitetura de estruturas técnicas e sociais de produção de conhecimento. Posso ajudar em muitos gêneros de projetos que se enquadram nessas duas grandes esferas: mapas ou visualizações, análise textual, arquivos digitais de artefatos culturais, edições digitais de documentos históricos e muito mais. Em alguns casos, fico disponível apenas para uma consulta rápida, em outros, dou cursos sobre esses temas ou uso um projeto como oportunidade para lecionar esses temas e, em alguns casos, foco em projetos especiais como membro da equipe.

\section{PALIMPSESTO}

2) Você tem uma gama impressionante de projetos em andamento. Ficamos particularmente interessados por $E d$., uma plataforma digital para editar textos literários que "pode produzir edições acadêmicas belamente renderizadas ou edições para leitura de textos destinados a durar". Como os entusiastas das humanidades digitais podem começar a trabalhar com uma plataforma como essa? Você acha que uma educação em programação é uma habilidade chave para um profissional das humanidades trabalhar com ferramentas e métodos digitais ou uma equipe transdisciplinar poderia atender a essa necessidade?

\section{ALEX GIL}


Ed é destinado a alunos intermediários. Você precisa aprender certos fundamentos de computação antes de poder usar algo como Ed independentemente de alguém que tenha essas habilidades para ajudá-lo. Para ser claro, as habilidades de que estou falando podem ser aprendidas sem fazer cursos de ciência da computação ou engenharia. Esses fundamentos são apenas a ponta do iceberg do que se aprende nesses cursos. Surpreendentemente, porém, você pode ir muito longe apenas com o básico. Sei bem disso, pois isso [o básico] é tudo que sei. Dito isso, não acredito que aprender esses fundamentos seja para todos. Isso é destinado àqueles que realmente desejem controlar a produção de seu próprio conhecimento; ou àqueles que realmente querem entender o que os algoritmos estão dizendo ou não sobre seus objetos de estudo.

Para responder à sua pergunta de forma ainda mais específica, acho que algumas equipes interdisciplinares são algo bom. Às vezes, essa "interdisciplinaridade" vem de dentro das próprias humanidades. Tudo que você precisa é de um ou dois programadores em uma equipe de humanistas para fazer a maioria dessas coisas. Eu mesmo tenho doutorado em literatura. Se você me tiver em sua equipe, talvez não precise de um engenheiro ou cientista da computação. Na verdade, convidar alguém dessas áreas seria excessivo. Quando pensamos no mundo profissional para além dos professores e bibliotecários, essa "interdisciplinaridade" adquire um significado diferente. Agora estamos falando de diferentes empresas e instituições "colaborando" no mercado. Pense em como um livro é feito. Diversas indústrias são "colaboradoras" na produção, distribuição e manejo de cada um desses objetos, mas isso só é possível porque esse objeto se torna uma mercadoria. Os projetos digitais não estão muito longe dessas ecologias de mercado, e muitas equipes de humanistas hoje contam com empresas que fornecem engenheiros e designers. Se esta é ou não a melhor maneira de criar nossos artefatos ou fazer nossa pesquisa, é uma questão diferente.

\section{PALIMPSESTO}

3) Temos visto, nos últimos anos, um aumento de tendências totalitárias e até mesmo de discursos neofascistas em vários países. Embora as mídias sociais muitas vezes desempenhem um papel importante na denúncia de abusos e brutalidade policial para um público internacional mais amplo, parece que elas também foram instrumentalizadas pela extrema direita para organizar, promover desinformação em massa e naturalizar 
discursos problemáticos. No Brasil, políticos e funcionários de alto escalão do atual governo foram recentemente acusados de dog wbistling neonazista em postagens no Twitter e em transmissões ao vivo no YouTube ao participarem de algo chamado de "Desafio do Leite" (Cf. SACONI, 2020). Você acha que as ferramentas e as tecnologias das humanidades digitais podem nos ajudar a expor e a desarticular tais práticas? Como?

\section{ALEX GIL}

Receio que o trabalho 'tecnológico' mais importante precise vir das empresas que fornecem essas plataformas que facilitam a divulgação dessas campanhas para início de conversa. Dito isso, você deve continuar a produzir artefatos culturais que lutem astutamente contra essas pessoas e a mensagem delas. Lute contra eles com qualquer ferramenta que você tiver à sua disposição, até as mesmas plataformas. E lembre-se, na questão de nos livrarmos do Bolsonaro e do fascismo no Brasil, ou do Trumpismo nos EUA, temos apenas duas opções: a revolução ou o voto. Talvez você possa usar as técnicas e práticas das humanidades digitais para contar histórias ou para compartilhar conhecimento que motivará as pessoas a fazer uma dessas duas coisas. Seja claro sobre qual você está escolhendo e se dedique a ele.

No entanto, livrar-nos dos fascistas não é o fim da história. Já estivemos aqui antes na história da humanidade. Provavelmente, seja qual for o seu projeto, ele contará essas histórias ou compartilhará esse conhecimento, abordando um ou dois dos sintomas desses governos, mas também o legado dos últimos 500 anos. Isso tudo é bom, porque você pode precisar continuar depois que os fascistas se forem. Veja, por exemplo, nosso projeto Torn Apart/Separados, contra a força policial Immigration Control and Enforcement (ICE). Imaginamos que teremos que continuar trabalhando contra eles por muito depois que Trump se for.

\section{PALIMPSESTO}

4) Você é um dos fundadores do Group for Experimental Methods in the Humanities [Grupo para Métodos Experimentais nas Humanidades] na Columbia, um grupo que não mantém uma lista oficial de membros, compartilhando em vez disso uma lista de colaboradores e nomeando os moderadores do grupo, os quais os interessados podem contactar para saber como podem participar. Vocês perceberam um aumento de pedidos 
de pessoas interessadas em colaborar com vocês desde o início da pandemia? Você acredita que o distanciamento social levará mais pessoas nas humanidades a experimentarem métodos digitais em suas práticas de ensino a longo prazo, por exemplo?

\section{ALEX GIL}

Não vimos um aumento no número de membros no xpmethod. Pelo contrário. Nós vimos uma redução. Nosso grupo geralmente se reunia às sextas-feiras na Butler Library na Columbia, em uma sala que administro chamada Butler Studio. Já que não podemos mais nos reunir, houve uma diminuição na participação ativa. Isso é perfeitamente compreensível. Alguns de nós já estão discutindo maneiras de tentar compensar essa ausência no semestre de outono usando técnicas como transmissões e envio de mensagens.

Sim, eu pessoalmente fui convidado a colaborar em muitos outros projetos desde o início da pandemia. Infelizmente, não posso aceitar todas as colaborações porque o tempo é finito. Eu acho isso ótimo, e só queria que houvesse muito mais profissionais como eu para que pudéssemos nos ajudar mutuamente nesse momento.

Sinceramente, não sei se as pessoas irão incorporar mais métodos digitais de forma permanente a longo prazo. Talvez haja um ligeiro aumento porque até o fim da pandemia eles terão alguma prática. É difícil prever.

\section{PALIMPSESTO}

5) Você e o Prof. Samuel Roberts anunciaram recentemente um novo projeto intitulado Bearing Witness, "um esforço para documentar e interpretar os eventos associados à nova epidemia de coronavírus nos Estados Unidos no que diz respeito às minorias racializadas". Torn Apart/Separados, é mais um de seus projetos que empregam saberes digitais para aumentar a consciência social e ajudar a promover mudanças. Você poderia nos contar um pouco mais sobre as intervenções do Mobilized Humanities?

\section{ALEX GIL}

A ideia é simples: use o que você sabe para tornar o mundo um lugar melhor, para lutar, para se rebelar contra o mal. Sabemos muito nas humanidades: sabemos a 
história, como ler atentamente, como ensinar, como argumentar, como contar histórias, como organizar o conhecimento, como fazer pesquisa, como produzir crítica, questionar o que nos é dito e, sim, como codificar, como fazer sites interativos, documentários, podcasts, livros e muito mais. Devemos usar tudo isso para reagir com luta, para dar testemunho do mal, para marcar presença e até mesmo para salvar vidas. Se tudo o que fazemos é contribuir para algum conhecimento enciclopédico do mundo, falhamos no presente que é vida.

\section{PALIMPSESTO}

6) Você é um renomado pesquisador de Aimé Césaire, responsável pela descoberta do manuscrito mais antigo conhecido de Et les chiens se taisaient. Como você se tornou um leitor de Césaire e por que decidiu escrever sua tese sobre ele? O que podemos aprender com Césaire em um momento de crise como o que vivemos em 2020 ?

\section{ALEX GIL}

Aimé Césaire é imensamente relevante, talvez mais do que quando comecei a estudar sua poesia e teatro na pós-graduação. Comecei a trabalhar com a obra dele na mesma época em que comecei a flertar com as humanidades digitais. Eu estava interessado em fazer um banco de dados de autores caribenhos naquela época. Fiz parceria com um professor do departamento de francês da Universidade da Virgínia que era pesquisador de Césaire, então concordei em começar por lá, fazendo uma edição digital de sua obra-prima, Cahier d'un retour au pays natal. Pouco tempo depois, eu estava escrevendo uma tese sobre o poeta.

Césaire é uma figura tão rica, e nos deu tanto, que para mim é difícil cobrir todas as formas em que sua obra é relevante hoje. Recomendo que você leia "Discours sur le colonialisme" ("Discurso sobre o colonialismo") para começar. Neste ensaio poderoso, ele argumenta que as técnicas do colonialismo voltarão para destruir as sociedades europeias. Hoje vemos bandidos do governo vestidos com trajes militares colocando cidadãos em veículos sem identificação nos Estados Unidos, supostamente a "maior democracia do mundo". Esses mesmos bandidos vestidos com trajes militares estavam colocando cidadãos em veículos sem identificação ontem no mesmo país. "Ilegais" era como eles os chamavam. Este é um exemplo do efeito bumerangue que Césaire 
descreve neste ensaio. É em sua poesia e em seu teatro, é claro, que encontro o tesouro muito mais rico: de receitas contra a assimilação a manuais de governança de sociedades pós-coloniais. Não acredite apenas na minha palavra, vá e leia os livros dele.

\section{PALIMPSESTO}

7) A pandemia forçou muitas escolas e universidades a encontrar novos modelos de ensino e aprendizagem. Em muitos países, inclusive no Brasil, ela também exacerbou os padrões de desigualdade presentes em nossos sistemas educacionais. Enquanto para alguns alunos e pais a questão era como fazer as aulas funcionarem bem por meio de plataformas de videoconferência em um ambiente doméstico, outros não tinham equipamentos adequados ou mesmo uma conexão estável com a internet. Muitos alunos moram em casas pequenas, que compartilham com diversos familiares e não possuem um quarto próprio onde possam se isolar durante as aulas. O que você acha da atual virada para o ensino on-line e o que podemos fazer - como professores, pesquisadores e estudantes - para garantir que a crise causada pela pandemia não implique em mais exclusão para as pessoas que já enfrentam os efeitos da desigualdade social em suas vidas cotidianas?

\section{ALEX GIL}

Não sei se você percebeu quando estava fazendo sua pesquisa que estou interessado nesta ideia de "computação mínima": a redução de muitas formas de computação para atender às necessidades do trabalho nas humanidades no nível mais básico, evitando muitos custos que realmente não podemos pagar. "Ed" é um exemplo de projeto elaborado com essa computação mínima em mente. Tais reduções na computação ligadas à questão da necessidade parecem sempre nos forçar a estar cientes de nossas limitações precisas, mas também do potencial ao nosso redor - a verdade mais profunda de nosso ambiente material e vivido.

Passei a última década viajando pelos continentes, conversando com colegas ao redor do mundo, observando como acadêmicos, bibliotecários e outros trabalhadores culturais conduzem seus trabalhos em ambientes muito diferentes: de lugares sem eletricidade constante a lugares com forte censura governamental. Ao longo dessas experiências, sempre carreguei comigo as ideias do arquiteto e teórico cubano Ernesto Oroza, que fala em "Arquiteturas de Necessidade" e "Moduladores Morais". Para ele, um dos maiores superpoderes dos necessitados é a capacidade de ver os reais 
componentes materiais dos objetos ao nosso redor: o que tem esse metal, para que isso serviria se o partisse em dois, etc. Ambos comunismo e capitalismo, ele aponta, dependem demais da ideia de um produto acabado, de uma mercadoria. Talvez seja esse o principal motivo pelo qual países como o meu, a República Dominicana, e o seu, o Brasil, confiam tanto em soluções tecnológicas importadas, em "ferramentas e softwares de humanidades digitais", por assim dizer. Em vez disso, convido você a olhar ao redor e ver o que você já tem à sua disposição. Só nesta máquina que você está usando para ler minhas palavras, você tem um computador relativamente poderoso, capaz de fazer cálculos, de automatizar tarefas fora das interfaces gráficas. Você sabe como usá-lo para fazer isso?

\section{PALIMPSESTO}

8) No Brasil, as universidades públicas têm sofrido ataques sistemáticos ao longo dos últimos anos. Nosso ex-Ministro da Educação (que deixou o cargo em junho de 2020) atacou frequentemente as Humanidades ao longo do período que passou no cargo, tendo declarado no início deste ano que "todas as universidades que a gente tem, não brota da terra o dinheiro, vem do imposto. Quando a gente for comprar pão, gasolina para a moto, telefone celular, vem imposto. E esse imposto é usado para pagar salário de professor, de técnico, bolsa, alimentação, tudo isso. Eu, como brasileiro, eu quero ter mais médico, mais enfermeiro, mais engenheiro, mais dentistas. Eu não quero mais sociólogo, antropólogo, não quero mais filósofo com o meu dinheiro". No ano passado, ele recebeu o apoio do presidente em sua proposta de reduzir os investimentos em cursos de Filosofia para priorizar áreas que, em sua visão, poderiam "gerar um retorno real", como "Enfermagem, Veterinária, Engenharia e Medicina". Os cursos de graduação e pós-graduação em Letras também foram excluídos do plano de investimentos quadrienais de uma das principais agências de fomento científico do país, o CNPq. Em um contexto como este, você acha que as ferramentas e práticas das humanidades digitais poderiam nos ajudar a tornar o trabalho que é desenvolvido na universidade mais amplamente visível e disponível para a sociedade em geral? Como as humanidades poderiam trabalhar para criar e empregar ferramentas tecnológicas para desconstruir preconceitos e argumentar contra discursos como o citado acima?

\section{ALEX GIL}

Você não vai ganhar com essas pessoas. Pare de tentar convencê-los. Você precisa se livrar deles, e daqueles três passos à esquerda deles, até cruzar o centro para a 
esquerda real que considera que a Vida humana é mais do que saúde e dinheiro. Essas pessoas são idiotas perigosos, sinceramente. Nós também os temos mais ao norte. Lembre-se de que provavelmente você perderá. Todos nós perderemos. Precisamos começar a imaginar um mundo em que as Humanidades (história, artes, teoria, crítica, etc.) existam pós-Universidades. Em um sentido real, em muitos países as Humanidades já vivem neste mundo. Este outro mundo está tentando lhe dizer algo. Se você deseja realmente compreender o poder dessas ferramentas, imagine-as servindo a você neste outro mundo.

Para ajudá-la a ver esse outro mundo, convido você a se debruçar um pouco sobre o domínio das bibliotecas piratas como SciHub e LibGen, e outras formas de pirate care [cuidado pirata] florescendo ao nosso redor. Não pedimos para viver em um mundo em que se importar é um crime, mas realmente devemos ficar bons nisso até que possamos nos livrar deste bando selvagem de burros demoníacos com os quais fomos amaldiçoados neste período da história da humanidade.

Obrigado por essas perguntas muito inteligentes e, novamente, por me dar a oportunidade de compartilhar algumas de minhas ideias com seus leitores. Seus professores têm muita sorte!

\section{Referências}

GIL, Alex. @elotroalex. Disponível em: https://www.elotroalex.com/. Acesso em: 25 Ago. 2020.

GIL, Alex. Design for Diversity: The Case of Ed / Alex Gil. Disponível em: https://des4div.library.northeastern.edu/design-for-diversity-the-case-of-ed-alex-gil. Acesso em: 25 Ago. 2020.

GO::DH. Minimal Computing. Disponível em: http://go-dh.github.io/mincomp/. Acesso em: 25 Ago. 2020.

MOBILIZED HUMANITIES. Torn Apart/Separados. Disponível em: http://xpmethod.columbia.edu/torn-apart/volume/2/index. Acesso em: 25 Ago. 2020.

PIRATE CARE. syllabus ३Pirate Care. Disponível em: https://syllabus.pirate.care/. Accessed on 25 Ago. 2020.

SACONI, João Paulo. Entenda: por que o copo de leite na live de Bolsonaro provocou controvérsia. O Globo. 01 Jul. 2020. Disponível em: 
https://blogs.oglobo.globo.com/sonar-a-escuta-das-redes/post/entenda-por-que-o-copode-leite-na-live-de-bolsonaro-provocou-controversia.html Acesso em: 25 Ago. 2020.

TORRENT, Susanna Allés; CATAPANO, Terry; GIL, Alex; GILLIUM, Johann. Ed. Disponível em: http://elotroalex.github.io/ed/. Acesso em: 25 Ago. 2020.

\footnotetext{
${ }^{1}$ Minimal computing: http://go-dh.github.io/mincomp/

${ }^{2}$ Check: https://des4div.library.northeastern.edu/design-for-diversity-the-case-of-ed-alex-gil/

${ }^{3}$ Pirate care: https://syllabus.pirate.care/
} 